\title{
Modal Intelektual, Budaya Perusahaan dan Kinerja Keuangan pada Sektor Perbankan Indonesia
}

\author{
Dahyang Ika Leni Wijayani ${ }^{1 *}$, Aditya Achmad Rakim ${ }^{2}$, Dian Saripujiana ${ }^{3}$, Hasto Finanto ${ }^{4}$ \\ ${ }^{1,2,4}$ Politeknik Negeri Balikpapan \\ ${ }^{3}$ STIE Madani Balikpapan \\ *dahyang.ika@poltekba.ac.id
}

\begin{abstract}
This study examines whether intellectual capital and corporate culture affects financial performance in Indonesia. Data are drawn form 34 sample of publicly bank that listed in Indonesia Stock Exchange (IDX). Intellectual capital using VAIC method and the four type of corporate culture (collaboration oriented/COL, control oriented/CON, competition oriented/COM dan creation oriented/CRE) using ATLAS.ti following the bag of words by Fiordelisi \& Ricci (2014). We find evidence that intellectual capital, collaboration oriented - culture (COL), creation - oriented culture (CRE). Competition - oriented culture (COM) are negatively and significanly related to financial performance, while the last type of corporate culture: control - oriented culture (CON) has not significanlly effect to financial performance.Intellectual capital become more important to the business and have a positif impact to financial performance. Collaboration oriented - culture (COL) that focus on team work, empowerment, participation, commitement and loyalty can increase the financial performance. Competition - oriented culture (COM)focus on market with high marketing cost, so can decrease the financial performance. Control oriented culture (CON) is traditional culture, imperfectly imitable, and many organization appliedit, so this culture has not an effect to financial performance. Company with creation - oriented culture (CRE)are high adaptable, create innovation, so it can increase the financial performance.
\end{abstract}

Keywords: corporate culture, intellectual capital, financial performance, banking sector

\begin{abstract}
Abstrak
Tujuan penelitian ini adalah menguji pengaruh modal intelektual dan budaya perusahaan terhadap kinerja keuangan dengan objek 34 bank - bank yang terdaftar di Bursa Efek Indonesia Periode 2017.Modal intelektual mengikuti model VAIC oleh Pulic (1998), sedangkan variabel budaya perusahaan dihitung menggunakan model Cameron \& Quinn (2006) sesuai bag of words yang dikembangkan oleh Fiordelisi \& Ricci (2014).Dari pengujian hipotesis diperoleh hasil bahwa modal intelektual berpengaruh positif dan signifikan terhadap kinerja keuangan.Budaya collaboration oriented (COL) dan creation - oriented (CRE) berpengaruh positif dan signifikan terhadap kinerja keuangan. Budaya competition - oriented (COM) berpengaruh negatif dan signifikan terhadap kinerja keuangan, sedangkan budaya control - oriented $(C O N)$ tidak berpengaruh terhadap kinerja keuangan. Modal intelektual akan menjadi bagian yang sangat penting dalam menjalankan bisnis perusahaan dan akan membawa dampak yang baik bagi kinerja keuangan perusahaan. Budaya collaboration - oriented culture (COL) berorientasi team work dan memiliki fokus pada pemberdayaan, partisipasi, komitmen dan loyalitas karyawan)dan memiliki dampak positif dalam meningkatkan kinerja keuangan.Budaya competition - oriented (COM) memiliki orientasi pasar dan memiliki biaya pemasaran yang tinggi, sehingga dianggap dapat membebani perusahaan dan oleh karenanya menurunkan kinerja keuangan.Control - oriented culture merupakan budaya yang tradisional dan sudah diterapkan oleh perusahaan sejak dulu, bukan budaya yang langka dan imperfectly imitable oleh karenanya budaya ini tidak akan mempengaruhi kinerja perusahaan.Perusahaaan yang memiliki tingkat adaptasi tinggi (creation oriented / CRE), tanggap terhadap perubahan dan selalu memunculkan inovasi, dan oleh karenanya akan memiliki kinerja keuangan yang baik dibandingkan dengan yang tidak.
\end{abstract}

Kata kunci: budaya perusahaan, modal intelektual, kinerja keuangan, sektor perbankan 


\section{Pendahuluan}

\subsection{Latar Belakang}

Tujuan utama perusahaan adalah memaksimalkan laba dan kekayaan dengan memperhatikan hak-hak para pemegang saham. Perusahaan memperoleh dana dari pemegang saham dan kreditor dalam membiayai investasi. Pengukuran efektivitas kinerja perusahaan dapat menggunakan beberapa rasio-rasio keuangan.Return-on-Assets (ROA) and Return-on-Equity (ROE) merupakan rasio keuangan yang paling sering digunakan (Kangarlouei, et al., 2012:172).ROE adalah rasio profitabilitas yang menunjukkan jumlah laba yang dihasilkan perusahaan terhadap ekuitas pemegang saham yang disajikan dalam bentuk persentase.

Sejak tahun 1990-an, perhatian praktek pengelolaan aset tidak berwujud (intangible assets) telah meningkat secara drastis (Harrison and Sullivan, 2000).Praktek akuntansi tradisional tidak menyajikan identifikasi dan pengukuran asset intangibles dalam organisasi, khususnya organisasi yang berbasis pengetahuan (Guthrie et al 1999; IFA 1998; Society of Management Accountants of Canada, 1998).Penilaian dan pengukuran intangible asset dapat menggunakan intellectual capital sebagai fokus perhatian dalam berbagai bidang, baik manajemen, teknologi informasi, sosiologi, maupun akuntansi (Petty dan Guthrie, 2000; Sullivan dan Sullivan, 2000).Intellectual capitalmerupakan salah satu instrumen untuk menentukan nilai perusahaan (Stewart 1997; Edvinsson and Malone 1997; Sveiby 2001).Aset dihasilkan melalui inovasi, praktik organisasi, sumber daya manusia atau kombinasi, aset fisik, dan karyawan (Lev, 2001).Pengukuran kinerja perusahaan dan intellectual capitalasset juga dapat dilihat melalui pergerakan harga saham serta membandingkan antara nilai buku dan nilai pasar (Brennan and Connel, 2000). Rasio market to book perusahaan pada indeks Standard \& Poor's 500 berkisar pada angka 6, hal ini mengalami kenaikan jika dibandingkan tahun 1980-an pada angka 1.0 (Lev, 2001).

Shiu (2006) menemukan VAIC (Value Added Intellectual Capital) - salah satu alat ukur intellectual capital,akan memberikan pengaruh terhadap pertumbuhan kinerja perusahaan, baik dengan pengukuran return on asset,return on equity, serta nilai pasar. Keefektifan penggunaan sumber daya manusia serta intellectual capitalakan memberikan dampak pada kinerja perusahaan, intellectual capital memiliki peran penting dalam meningkatkan kinerja perusahaan dan nilai perusahaan, serta akan memberikan kepercayaan perusahaan oleh investor sehingga akan mempengaruhi market value perusahaan (Goh, 2005; Chen et al, 2005; Belkaoui, 2003; Firrer and Williams, 2003; Pulic, 2000; Edvinsson dan Malone, 1997).

Huang dan Liu (2005) menyatakan bahwaintellectual capital tidak memiliki hubungan terhadap kinerja perusahaan. Pemanfaatan intellectual capital ketika dilakukan melebihi tingkat optimal, maka investasi terhadap intellectual capital tersebut justuakan memberikan dampak negatif pada kinerja perusahaan. Koordinasi antara modal investasi serta komponen-komponen lain dalam intellectual capital sangat diperlukan agar mendapatkan keunggulan kompetitif bagi korporasi.

Marcoulides dan Heck (1993) dalam Brahmasari (2004:16) mengemukakan bahwa budaya organisasi sebagai suatu konsep dapat menjadi suatu sarana untuk mengukur kesesuaian dari tujuan organisasi, strategi dan organisasi tugas, serta dampak yang dihasilkan.Moeljono Djokosantoso (2003:17-18) menyatakan bahwa budaya korporat atau budaya manajemen atau budaya korporasi merupakan nilai-nilai dominan yang disebarluaskan didalam organisasi dan diacu sebagai filosofi kerja karyawan.Culture can be characterized by trust in subordinate, open communication, considerate and supportive leadership, group problem solving, worker autonomy, information sharing and high output goal (Mondy dan Noe, 1990:87).Budaya organisasi adalah suatu sistem nilai yang dirasakan maknanya oleh seluruh orang dalam perusahaan.Pemahaman pada seluruh jajaran menyakini sistem nilai tersebut sebagai landasan gerak perusahaan (Siagian, 2002:201). 
Penelitian terdahulu yang dilakukan oleh Zhao et al (2018), Djuanda dan Tarigan (2016); Rakim (2014); Hermanto dan Rusdin (2013); Rashid, Sambasivan and Johari (2002) menyatakan adanya pengaruh antara corporate culture dan kinerja keuangan. Budaya perusahaan dapat memberikan dampak pada kinerja perusahaan melalui: peningkatan koordinasi dan kontrol dalam perusahaan, peningkatan keselarasan tujuan antara manajemen perusahaan dan anggota, dan peningkatan kreatifitas karyawan (Sorensen, 2002). Budaya korporat sebagai nilai yang diyakini oleh anggota organisasi yang harus dibangun disesuaikan dengan strategi yang akan diterapkan oleh perusahaan, sehingga budaya yang terbentuk dapat berjalan dengan baik dan berpengaruh pada kinerja perusahaan sehingga perusahaan akan sukses berkelanjutan dan tercipta keunggulan kompetitif bagi perusahaan (Arianingsih, 2011). Budaya perusahaan akan memperkuat semangat kewirausahaan sehingga menciptakan iklim lingkungan kerja yang baik dan akan berdampak kepada kinerja perusahaan (Hill dan Steward, 2007; Allen dan Wright, 2007).

Penerapan budaya perusahaan yang buruk akan berdampak bagi kinerja perusahaan terutama dalam jangka panjang, beberapa perusahaan seperti Sears, Bank of America, dan General Motors merupakan contoh dikarenakan penerapan budaya perusahaan yang buruk. Kegagalan serta kesulitan dalam merger dan akuisisi yang disebabkan konflik budaya perusahaan dapat mengakibatkan hilangnya manfaat dari sinergi merger dan akuisisi (O'Relly, 1989).

Riset dengan tema intellectual capitaldan budaya perusahaan yang berpengaruh terhadap kinerja keuangan, masih sangat jarang ditemukan di Indonesia.Jika ada pun, tidak menggabungkan diantara keduanya.Masing - masing variabel tersebut berdiri sendiri - sendiri, seperti penelitian Ulum (2008); Ciptaningsih (2013); dan Sutanto \& Siswantaya (2014).Penelitian ini menguji pengaruh modal intelektual, budaya perusahaan terhadap kinerja keuangan pada perusahaan sektor perbankan terdaftar di BEI pada tahun 2017.Dalam dunia internasional, sektor perbankan dan keuangan menjadi fokus studi terhadap modal intelektual. Mohiudiin et al. (2006) dalam Joshi et al. (2012) menemukan bahwa semua bank - bank dalam riset empirisnya di Bangladesh, mempunyai skor intellectual capital yang tinggi dibandingkan dengan perusahaan lainnya. Perusahaan perbankan dianggap high intellectual dibandingkan dengan jenis perusahaan lain dan oleh karenanya riset ini menggunakan objek pada sektor perbankan.

\subsection{Kerangka Penelitian dan Hipotesis Budaya Perusahaan}

Definisi budaya organisasi telah banyak dirumuskan oleh berbagai literatur. Schein (2004) mendefinisikan the culture of a group sebagai sebuah pola dari asumsi dasar yang dipelajari secara bersama-sama oleh suatu kelompok tertentu yang dianggap baik dan valid, dan oleh karenanya perlu diajarkan kepada pihak lain sebagai panduan yang benar untuk memahami, berpikir dan merasa memiliki hubungan yang sama untuk suatu permasalahan tertentu. Definisi lain dikemukakan oleh Cameron dan Quinn (2006) yang mendefinisikan budaya sebagai kebiasaan, kesepakatan dan seperangkat persepsi, ingatan, nilai, sikap yang membuat sebuah organisasi mempunyai keunggulan kompetitif. Porter mengidentifikasi bahwa keberhasilan sebuah organisasi dilihat dari profitabilitas yang berkelanjutan dan memiliki tingkat pengembalian keuangan yang baik (Cameron dan Quinn, 2006).Akan tetapi perusahaanperusahaan sukses di Amerika Serikat seperti Southwest Airline dan Wal-Mart tidak memasuki pasar dengan posisi mendominasi market share dan bahkan tanpa competitive advantage.Cameron (2006) menjelaskan bahwa keberhasilan perusahaan-perusahaan tersebut dikarenakan adanya sebuah budaya perusahaan yang merupakan suatu hal yang less tangible, less blatant, but more powerful than the market factors. Budaya perusahaan merupakan kombinasi dari nilai perusahaan, keyakinan pribadi dan visi yang bisa dibentuk oleh pendiri perusahaan dan atau muncul dari waktu ke waktu seiring perkembangan organisasi dalam mengatasi hambatan 
dalam lingkungan bisnisnya dan atau sengaja dibangun oleh manajemen untuk meningkatkan kinerja dengan cara yang sistematis.

\section{Modal Intelektual/Intellectual Capital}

Dominasi aktivitas ekonomi pada masa sekarang bukan lagi produksi barang, akan tetapi produksi pengetahuan yang kemudian ditransformasikan menjadi barang dan jasa (Pulic, 2008). The production of knowledgedirepresentasikan dalam bisnis sebagai intellectual capital.Dalam konsep ekonomi modern, definisi intellectual capital menurut Pulic (2008) adalah "intellectual capital is used as a synonym for those employees, who have the capability of transforming and incorporating knowledge into product and services that create value.

Definisi lain menurut IASB (2004), IC are non-financial fixed assets that do not have financial substance but are identifiable and controlled by the entity through custody and legal rights.

Dari beberapa literatur, tidak ada yang menyimpulkan secara pasti definisi dari intellectual capital, akan tetapi dari dua definisi di atas dapat disimpulkan bahwa terdapat dua aspek yaitu intellectual capital yang digambarkan sebagai intagible asset seperti paten, trademark, merk dan yang memandang intellectual capital sebagai soft assetseperti pengetahuan, informasi, pengalaman, berhubungan erat dengan kapasitas sumber daya manusia. Dalam riset kali ini, intellectual capital dipandang menggunakan aspek yang kedua.

\section{Stakeholder Theory}

Konsep stakeholder theory pertama kali dikembangkan oleh Freeman (1984) yang merekomendasikan model bisnis perusahaan yang memperhatikan kepentingan para stakeholders(customers, employess, suppliers, governments, environment,dll). The task of executives is to create as much value as possible for stakeholders without resorting to tradeoffs. Great companies endure because they manage to get stakeholder interests aligned in the same direction (Freeman, 2010). Perusahaan akan bisa bertahan jika mampu mengatur kepentingan para stakeholders sejalan dengan kepentingan bisnis perusahaan tesebut dan menciptakan nilai bagi mereka. Salah satu bentuk perwujudan stakeholders theory adalah pengungkapan intellectual capital di dalam informasi publikasi perusahaan. Pengungkapan IC secara sukarela akanbisa meningkatan kepuasan para pemangku kepentingan. Nurhayati dan Uzliawati (2017) menjelaskan bahwa pengungkapan intellectual capital merupakan bagian dari komunikasi perusahaan dengan para pemangku kepentingan dan di Indonesia harapan para pemangku kepentingan sektor perbankan di Indonesia terhadap pengungkapan item intellectual capitalmasuk dalam skor yang tinggi.

\section{Resource Based Theory}

Resource based theorymenurut Edward (2012) adalah kepemilikan sumber daya strategis yang akan memberikan peluang bagi organisasi untuk mengembangkan keunggulan kompetitif dari para pesaingnya. Barney (1991) dalam Edward (2012) mengelompokkan keunggulan kompetitif menjadi 4 hal yaitu: valuable, rare, difficult to imitate, dan non substitutable. Sumber daya dan kemampuan merupakan landasan utama organisasi dalam menciptakan strategi.Sumber daya secara garis besar dibedakan menjadi dua yaitu tangible resource dan intangible resource. Intangible resourcesare more likely to meet the criteria for strategic resources (i.e., valuable, rare, difficult to imitate, and nonsubstitutable) than are tangible resources (Edward, 2012). Budaya perusahaan dan modal intelektual merupakan dua hal yang termasuk dalam intangible resource yang masuk dalam kemampuan organisasi dalam mencapai tujuan strategis berdasarkan resource based theory. Wesjet Airlines menjadi perusahaan penerbangan terbaik di Kanada dengan melakukan strategi optimalisasi corporate culture di dalam membangun strategi 
kompetitifnya terhadap para pesaing.Modal intelektual dan budaya perusahaan diyakini dapat membawa perusahaan mencapai keunggulan kompetitif dari para pesaingnya sebagai bagian dari upaya organsasi memaksimalkan intangible assetnya.

Kerangka penelitian digambarkan sebagai berikut:

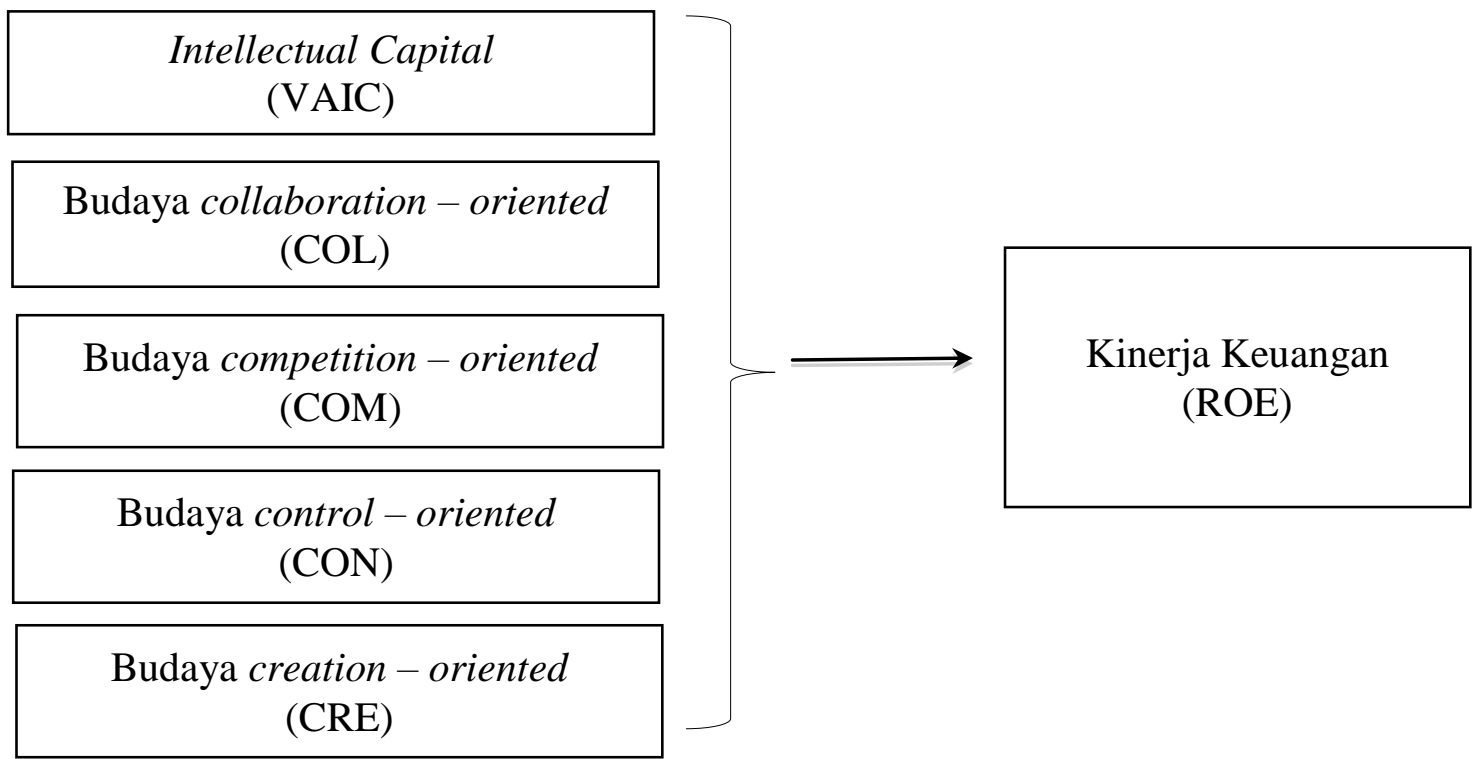

Gambar 1: Kerangka Penelitian

\section{Intellectual capital dan Kinerja Keuangan}

Clarke et al. (2011) meneliti pengaruh intellectual capitalterhadap kinerja perusahaan dengan objek penelitian perusahaan yang listing di Australia Stock Exchange, menyimpulkan bahwa human capital efficiencysebagai bagian dari VAIC merupakan elemen yang sangat penting dalam intellectual capital.Perusahaan - perusahaan di Australia memiliki banyak keuntungan dari investasinya terhadap skill dan pengetahuan karyawannya.Riset - riset empiris yang telah dilakukan banyak menyimpulkan bahwa intagible asset atau modal intelektual dari perusahaan berpengaruh besar terhadap kinerja keuangan perusahaan (Belkaoui, 2008; Firer, 2003; Gan \& Saleh, 2008; Joshi et al., 2013).

$H_{1}$ : Intellectual capital berpengaruh positif dan signifikan terhadap kinerja keuangan.

\section{Budaya collaboration - orienteddan Kinerja Keuangan}

Budaya berorientasikolaborasi/team workmemiliki asumsi dasar bahwa lingkungan dapat dikendalikan melalui kerjasama tim, pengembangan karyawan, berorientasi kemanusiaan. Fokus organisasi adalah pemberdayaan, partisipasi, komitmen dan loyalitas karyawan.Budaya perusahaan dapat mengembangkan komitmen karyawan terhadap organisasi dengan meningkatkan ikatan mereka terhadap perusahaan (O'Reilly, 1989 dalam Zhao et al., 2018).Budaya ini identik dengan integritas karyawan dikarenakan dalam budaya kolaborasi hubungan antara karyawan dengan perusahananya merupakan hubungan saling terkait dan menguntungkan, mencerminan loyalitas karyawan terhadap perusahaannya.Zhao et al. (2018) dalam penelitiannya dengan objek perusahaan listing di China menyimpulkan bahwa integritas memiliki hubungan dengan nilai perusahaan dan kinerja keuangan.

$\mathrm{H}_{2}$ : Budaya collaboration - oriented $(\mathrm{COL})$ berpengaruh positif dan signifikan terhadap kinerja keuangan. 


\section{Budaya competition - orienteddan Kinerja Keuangan}

Budaya competition - orientedmenempatkan organisasi bisnis sebagai fungsi dari pasar, berorientasi eksternal seperti pemasok, konsumen, kontraktor, dll.Perusahaan dengan budaya ini pada umumnya banyak melakukan promosi untuk memperkenalkan produknya.Zhao et al. (2018) menyimpulkan bahwa budaya perusahaan berorientasi promosi mempunyai efek yang negatif dan signifikan terhadap nilai dari perusahaan.

$\mathrm{H}_{3}$ : Budaya competition - oriented (COM) berpengaruh negatif dan signifikan terhadap kinerja keuangan.

\section{Budaya control - orienteddan Kinerja Keuangan}

Budaya perusahaan dapat meningkatkan efisiensi melalui peningkatan koordinasi dan kontrol organisasi (Zhao et al., 2018).Budaya berorientasi kontrol/hirarki dikelola melalui aturan, pekerjaan khusus, dan keputusan yang tepat.O'Reilly dalam Zhao et al(2018) menyatakan bahwa tanpa sistem kontrol dalam organisasi, hanya sedikit hal yang akan bisa diselesaikan. Budaya perusahaan ini membantu karyawan berinteraksi dan terhubung satu sama lain, dan hal ini dapat meningkatkan efisiensi dan pertukaran informasi (Jacobs et al., 2013; Cremer, 1993 dalam Zhao et al., 2018).

$\mathrm{H}_{4}$ : Budaya control - oriented (CON) berpengaruh positif dan signifikan terhadap kinerja keuangan.

\section{Budaya creation - orienteddan Kinerja Keuangan}

Tipe budaya ini mengedepankan inovasi dan inisiatif yang dianggap akan membawa arah sumber daya baru, visi masa depan dan meningkatkan profitabilitas. Deshpande \& Farley (1999) dalam Rashid (2003) menemukan bahwa budaya kompetitif banyak ditemukan dalam perusahaanperusahaan besar dan sangat sukses di Jepang dibandingkan jenis budaya lainnya. Budaya kompetitif akanmembuat perusahaan memiliki daya saing yang baik di pasar dan akan dapat meningkatkan laba.

$H_{5}$ : Budaya creation - oriented (CRE) berpengaruh positif dan signifikan terhadap kinerja keuangan.

\section{Metodologi Penelitian}

\subsection{Variabel Kinerja Keuangan}

Variabel kinerja keuangan diukur menggunakan ROE (Return on Equity). ROE merupakan salah satu indikator kinerja keuangan dengan menggunakan rasio akuntansi berbasis laporan keuangan.Rasio ini merupakan rasio yang paling sering digunakan oleh investor, kreditor dan manajer dalam mengevaluasi kinerja keuangan perusahaan (Samiloglu, et al.,2017).ROE merupakan rasio profitabilitas yang mengindikasikan jumlah laba bersih perusahaan yang dihasilkan menggunakan \% dari jumlah modal (shareholder's equity). ROE merupakan salah satu alat ukur yang paling relevan dan digunakan secara luas dalam mengevaluasi kinerja perusahaan dan menganalisa laporan keuangan (Rappaport dalam Marchini \& D’Este, 2015).

$$
R O E=\frac{N I}{S E}
$$


Keterangan:

NI : Net Income

SE : Shareholder's Equity

ROE : Return on Equity

\subsection{Variabel Intellectual capital}

Intellectual capitalmenggambarkan pengetahuan sebagai sumber kekuatan utama dalam bisnis dan dalam konsep ekonomi modern menggambarkan sumber daya manusia/tenaga kerja yang mempunyai kemampuan dalam mentransformasikan dan menggabungkan pengetahuan ke dalam produk dan jasa yang menghasilkan nilai bagi perusahaan (Pulic, 2008).Variabel intellectual capital (VAIC) diukur menggunakan metode oleh Pulic (1998):

Langkah pertama menghitung VAICadalah menghitung komponen di bawah ini:

1. HC (Human Capital) menggambarkan biaya karyawan dari perusahaan.

2. VA (Value Added) menggambarkan laba operasional perusahaan = OUT - IN

3. CE (Capital Employed) menggambarkan book value of Total Asset

Langkah kedua menghitung VAIC adalah menghitung komponen di bawah ini:

1. VACE (Value Added Capital Employed) menggambarkan rasio VA terhadap CE yaitu menunjukkan seberapa besar kontribusi setiap unit dari book value of total asset terhadap value added organisasi.

$$
V A C E=\frac{V A}{C E}
$$

2. VAHC (Value Added Human Capital) menggambarkan rasio VA terhadap HC yaitu menunjukkan seberapa besar kontribusi setiap rupiah biaya karyawan terhadap value added organisasi.

$$
V A H C=\frac{V A}{H C}
$$

3. VAIC (Value Added Intellectual Capital) menggambarkan kemampuan intelektual perusahaan.

$$
V A I C=V A C E+V A H C
$$

\subsection{Variabel Budaya Perusahaan}

Budaya perusahaan diukur menggunakan model Cameron \& Quinn (2006) dengan metode Competing Values Framework (CVF). Meskipun ada beberapa tipologi budaya perusahaan, CVF merupakan salah satu model yang paling luas dan banyak digunakan dalam beberapa studi empiris budaya organisasi (Naranjo-Valencia et al., 2011).Cameron dan Quinn (2006) dalam risetnya menemukan kebanyakan organisasi menghasilkan satu gaya budaya yang dominan. Lebih dari $80 \%$ dari ribuan organisasi yang diteliti memiliki satu atau lebih karakteristik tipe budaya sesuai CVF.

Terdapat 2 dimensi budaya menurut CVF, yaitu dimensi internal daneksternal. Budaya dengan dimensi internal terdiri dari dua tipe yaitucollaboration-oriented culture(clan culture type/COL) 
dan control - oriented culture (hierarchy culture/CON). Sedangkan budaya dimensi eksternal dibagi menjadi dua tipe yaitu competition - oriented culture (market culture/COM) dan creation - oriented culture (adhocracy culture/CRE). Kriteria yang digunakan untuk mengukur tipe budaya tersebut mengikuti Fiordelisi \& Ricci (2014), menggunakan bag of words. Budaya perusahaan dihitung mengikuti bag of wordstersebut dan memasukkan setiap annual report perusahaan dalam aplikasi ATLAS.ti sehingga diperoleh hasil untuk keempat tipe budaya untuk setiap annual report perusahaan.Bag of words untuk setiap tipe budayaditunjukkan dalam tabel di bawah ini:

Tabel 1.The Fiordelisi and Ricci's Corporate Culture Bag of Words

\begin{tabular}{|c|c|}
\hline Culture Type & Bag of Words \\
\hline $\begin{array}{l}\text { Collaborate } \\
(\mathrm{COL})\end{array}$ & $\begin{array}{l}\text { boss*, burocr*, cautio*, cohes*, certain*, chief*, collab*, conservat*, cooperat*, detail*, } \\
\text { document*, efficien*, error*, fail }{ }^{*}, \text { help*, human*, inform*, logic*, method*, outcom*, } \\
\text { partner*, people*, predictab*, relation*, qualit*, regular*, solv*, share*, standard*, team*, } \\
\text { teamwork*, train*, uniform*, work group* }\end{array}$ \\
\hline $\begin{array}{l}\text { Control } \\
(\mathrm{CON})\end{array}$ & $\begin{array}{l}\text { capab*, collective*, commit*, competenc*, conflict*, consens*, control*, coordin, cultur*, } \\
\text { decentr*, employ*, empower*, engag*, expectat*, facilitator*, hir*, interpers*, involve*, } \\
\text { life*, long-term*, loyal*, mentor*, monit*, mutual*, norm*, parent*, partic*, procedur*, } \\
\text { productive*, retain*, reten*, skill*, social*, tension*, value* }\end{array}$ \\
\hline $\begin{array}{l}\text { Compete } \\
(\mathrm{COM})\end{array}$ & $\begin{array}{l}\text { achiev*, acqui*, aggress*, agreem*, attack*, budget*, challeng*, charg*, client*, compet*, } \\
\text { customer*, deliver*, direct*, driv*, excellen*, expand*, fast*, goal*, growth*, hard*, } \\
\text { invest*, market*, mov*, outsourc*, performance*, position*, pressur*, profit*, rapid*, } \\
\text { reputation*, result*, revenue*, satisf*, scan*, success*, signal*, speed*, strong*, } \\
\text { superior*, target*, win* }\end{array}$ \\
\hline $\begin{array}{l}\text { Create } \\
\text { (CRE) }\end{array}$ & 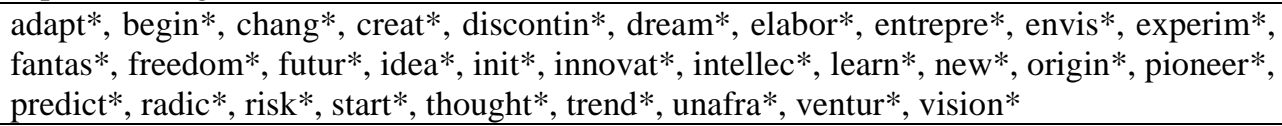 \\
\hline
\end{tabular}

Sumber: Fiordelisi \& Ricci (2014)

\subsection{Jenis Data dan Metode Pengumpulan Data}

Jenis data yang digunakan adalah data sekunder, yaitu data laporan keuangan dan annual report perusahaan yang diperoleh dari situs www.idx.co.id. Penelitian ini menggunakan objek bank - bank yang listeddi Bursa Efek Indonesia (BEI) periode 2017 mengikuti kriteria di bawah ini:

Tabel 2. Kriteria Sampel

\begin{tabular}{llc}
\hline No & \multicolumn{1}{c}{ Kriteria } & $\begin{array}{c}\text { Jumlah } \\
\text { Sampel }\end{array}$ \\
\hline 1. & Bank yang listed di BEI periode 2017 & 45 \\
\hline 2. & $\begin{array}{l}\text { Bank yang tidak mempunyai annual report dalam } \\
\text { Bahasa Inggris }\end{array}$ & $(0)$ \\
\hline 3. & Bank yang data laporan keuangannya tidak lengkap & $(0)$ \\
\hline 3. & $\begin{array}{l}\text { Bank yang annual report-nya tidak bisa diolah } \\
\text { menggunakan aplikasi ATLAS.ti }\end{array}$ & $(1)$ \\
\hline \multicolumn{3}{c}{ JUMLAH SAMPEL } \\
\hline
\end{tabular}

\subsection{Teknik Analisis Data}

Metode yang digunakan dalam analisis data adalah analisis statistik deskriptif dan analisis statistik inferensial yaitu regresi linier berganda (multiple regression) dengan program IBM SPSS 23.Metode multiple regressionadalah metode statistik untuk menguji hubungan antara satu variabel terikat dengan lebih dari satu variabel bebas (Ghozali, 2018). Analisis multiple 
regressiondigunakan untuk menguji signifikansi pengaruh masing - masing variabel independen terhadap variabel dependen, baik secara parsial (uji T) maupun simultan (uji F).Agar estimasi yang dihasilkan bersifat BLUE (Best Liniear Unbiased Estimator), maka dilakukan uji normalitas, multikolinearitas, heteroskesdatisitas dan autokorelasi.Model persamaan regresi adalah sebagai berikut:

$$
R O E=a+b_{2} \cdot V A C+b_{2} C O L+b_{3} C O M+b_{1} C O N+b_{5} C R E+\varepsilon
$$

Keterangan:

$\begin{aligned} \text { ROE } & =\text { Return On Equity } \\ \text { VAIC } & =\text { Value Added Intellectual Capital } \\ \mathrm{COL} & =\text { Budaya Collaborate } \\ \mathrm{CON} & =\text { Budaya Control } \\ \mathrm{COM} & =\text { Budaya Compete } \\ \mathrm{CRE} & =\text { Budaya Creation } \\ \mathrm{CAR} & =\text { Capital Adequacy Ratio } \\ \mathrm{NIM} & =\text { Net Interest Margin } \\ \mathrm{LDR} & =\text { Loan to Deposit Ratio } \\ \mathrm{SIZE} & =\text { Ukuran Perusahaan } \\ \mathrm{a}, \mathrm{b}_{1}-\mathrm{b}_{6} & =\text { Konstanta }\end{aligned}$

\section{Hasil dan Pembahasan}

\subsection{Analisis Statistik Deskriptif}

Tabel 3. Hasil Statistik Deskriptif

\begin{tabular}{llrrrr}
\hline \multicolumn{7}{c}{ Descriptive Statistics } \\
\hline & $\mathrm{N}$ & \multicolumn{1}{c}{ Minimum } & \multicolumn{1}{c}{ Maximum } & \multicolumn{1}{c}{ Mean } & \multicolumn{1}{c}{ Std. Deviation } \\
\hline VAIC & 34 &, 00 & 2,61 &, 7478 &, 64008 \\
\hline COM & 34 & $-2,07$ &,- 52 & $-1,0498$ &, 30649 \\
\hline COL & 34 &, 01 &, 08 &, 0401 &, 02004 \\
\hline CON & 34 &, 00 &, 18 &, 0670 &, 03921 \\
\hline CRE & 34 &, 01 &, 40 &, 1400 &, 09620 \\
\hline Valid N (listwise) & 34 & & & & \\
\hline
\end{tabular}

Sumber: data hasil olah dengan IBM SPSS 23, 2019

Berdasarkan hasil statistik deskriptif pada tabel 3 dapat diketahui bahwa:

1. Intellectual Capital (VAIC) memiliki nilai minimum 0 dan nilai maksimum 2,61 dengan nilai rata-rata 0,7478 .

2. Budaya perusahaancompetition - oriented culture (COM) memiliki nilai minimum -2,07 dan nilai maksimum -0,52 dengan nilai rata-rata $-1,0498$.

3. Budaya perusahaancollaboration-oriented culture (COL) memiliki nilai minimum 0,01 dan nilai maksimum 0,08 dengan nilai rata-rata 0,0401 .

4. Budaya perusahaancontrol - oriented culture $(\mathrm{CON})$ memiliki nilai minimum 0 dan nilai maksimum 0,18 dengan nilai rata-rata 0,067.

5. Budaya perusahaancreation - oriented culture(CRE) memiliki nilai minimum 0,01 dan nilai maksimum 0,40 dengan nilai rata-rata 0,14. 


\subsection{Uji Asumsi Klasik}

Dari 44 data yang telah memenuhi kriteria sampel, dilakukan screening data untuk mendeteksi adanya data outlier.Menurut Ghozali (2018), outlier adalah kasus atau data yang memiliki karakteristik yang sangat berbeda jauh dari observasi lainnya dan muncul dalam bentuk ekstrim. Adanya data outlier dapat memiliki pengaruh yang besar dalam kesimpulan hasil analisis statistikmultivariate (Hairet al., 2014).Hairet.al (2014:65) menjelaskan bahwa untuk kasus sampel kecil (kurang dari 80), standar skor dengan nilai $\geq 2,5$ dinyatakan outlier.

Dataoutliersebanyak 10 sampel yang teridentifikasi dikeluarkan dari sampel penelitian, sehingga jumlah data yang diolah adalah sebanyak 34 sampel.Berdasarkan tabel 4, data sudah memenuhi uji asumsi klasik untuk kemudian dilakukan uji multiple regression.

Tabel 4.Hasil Uji Asumsi Klasik

\begin{tabular}{|c|c|c|}
\hline Uji Asumsi & Hasil & Keterangan \\
\hline \multicolumn{3}{|l|}{ Uji Normalitas } \\
\hline Kolmogorov-Smirnov & 0,135 & Data berdistribusi \\
\hline Asymp. Sig. (2-tailed) & $\mathrm{p}$-value $=0,121(>0,05)$ & normal \\
\hline \multicolumn{3}{|l|}{ Uji Autokorelasi } \\
\hline Durbin Watson & $1,808(\mathrm{du})<2,155<2,192(4-\mathrm{du})$ & $\begin{array}{c}\text { Tidak ada autokorelasi, } \\
\text { baik positif/negatif }\end{array}$ \\
\hline \multicolumn{3}{|l|}{ Uji Multikolinearitas } \\
\hline Variance Inflation Factor (VIF) VAIC & 1,281 & Tidak ada \\
\hline Variance Inflation Factor (VIF) COL & 2,928 & multikolinearitas \\
\hline Variance Inflation Factor (VIF) COM & 5,219 & \\
\hline Variance Inflation Factor (VIF) CON & 1,408 & \\
\hline Variance Inflation Factor (VIF) CRE & 3,194 & \\
\hline \multicolumn{3}{|l|}{ Uji Heteroskesdatisitas } \\
\hline Hasil Uji Glejser VAIC & 0,256 & Tidak terjadi \\
\hline Hasil Uji Glejser COL & 0,418 & heteroskedastisitas \\
\hline Hasil Uji Glejser COM & 0,556 & (homoskesdatisitas) \\
\hline Hasil Uji Glejser CON & 0,972 & \\
\hline Hasil Uji Glejser CRE & 0,356 & \\
\hline
\end{tabular}

Sumber: data hasil olah dengan IBM SPSS 23, 2019

\subsection{Pengujian Hipotesis}

\subsubsection{Uji Koefisien Determinasi $\left(\mathbf{R}^{2}\right)$}

Hasil output analisis data dari uji koefisien determinasi adalah sebagai berikut:

Tabel 5. Hasil Koefisien Determinasi

\begin{tabular}{lcccc}
\hline \multicolumn{4}{c}{ Model Summary } \\
\hline Model & $\mathrm{R}$ & R Square & $\begin{array}{c}\text { Adjusted R } \\
\text { Square }\end{array}$ & $\begin{array}{c}\text { Std. Error of the } \\
\text { Estimate }\end{array}$ \\
\hline 1 & $.785^{\mathrm{a}}$ & .616 & .547 & .07351 \\
\hline a. Predictors: (Constant), VAIC, COL, COM, CON, CRE \\
\hline
\end{tabular}

Berdasarkan tabel 4, besarnya adjusted $R$ square adalah 0,547 yang berarti bahwa 54,7\% dari kinerja perusahaan yang diproksikan dengan ROE dapat dijelaskan oleh variasi variabel modal intelektual dan 4 tipe budaya perusahaan (COL, COM, CON, CRE). Sisanya yaitu sebesar $45,3 \%$ dijelaskan oleh faktor - faktor lain yang tidak diikutsertakan dalam model penelitian. 


\subsubsection{Uji Simultan (Uji F)}

Hasil output uji F adalah sebagai berikut:

Tabel 6. Hasil Uji F

\begin{tabular}{llrrrrr}
\hline \multicolumn{7}{c}{ ANOVA $^{\mathrm{a}}$} \\
\hline \multirow{2}{*}{1} & Sum of Squares & $\mathrm{df}$ & Mean Square & F & Sig. \\
\cline { 2 - 7 } & Regression & .243 & 5 & .049 & 8.985 & $.000^{\mathrm{b}}$ \\
\cline { 2 - 7 } & Residual & .151 & 28 & .005 & & \\
\cline { 2 - 7 } & Total & .394 & 33 & & & \\
\hline
\end{tabular}

a. Dependent Variable: ROE

b. Predictors: (Constant), VAIC, COL, COM, CON, CRE

Sumber: data hasil olah dengan IBM SPSS 23, 2019

Berdasarkan tabel 5, hasil $\mathrm{F}$ hitung adalah 8,985 dengan pada $\mathrm{p}$-value 0,000 sehingga dapat disimpulkan bahwa variabel modal intelektual (VAIC) dan empat tipe budaya perusahaan (COL, COM, CON, CRE) secara bersama - sama memiliki pengaruh yang signifikan terhadap kinerja perusahaan (ROE) pada bank yang listed di BEI periode 2017.

\subsubsection{Uji Parsial (Uji t)}

Hasil output uji t adalah sebagai berikut:

Tabel 7. Hasil Uji t

\begin{tabular}{|c|c|c|c|c|c|c|}
\hline \multicolumn{7}{|c|}{ Coefficients $^{a}$} \\
\hline & \multirow[b]{2}{*}{ Model } & Unstandardize & Goefficients & \multirow{2}{*}{$\begin{array}{c}\text { Standardized } \\
\text { Coefficients } \\
\text { Beta }\end{array}$} & \multirow[b]{2}{*}{$t$} & \multirow[b]{2}{*}{ Sig. } \\
\hline & & $B$ & Std. Error & & & \\
\hline \multirow[t]{6}{*}{1} & (Constant) & -.505 & .150 & & -3.366 & .002 \\
\hline & VAIC & .089 & .023 & .524 & 3.950 & .000 \\
\hline & $C O L$ & 2.795 & 1.093 & .513 & 2.558 & .016 \\
\hline & $C O M$ & -.311 & .095 & -.873 & -3.262 & .003 \\
\hline & $C O N$ & -.359 & .387 & -.129 & -.926 & .362 \\
\hline & CRE & .587 & .238 & .516 & 2.468 & .020 \\
\hline
\end{tabular}

a. Dependent Variable: ROE

Sumber: data hasil olah dengan IBM SPSS 23, 2019

Keterangan:

VAIC : Vallue Added Intellectual Capital

COL : Collaboration-oriented culture

COM : Competition-oriented culture

CON : Control-oriented culture

CRE : Creation-oriented culture

ROE : Return on Equity

Berdasarkan tabel 6, hasil uji t untuk masing - masing variabel independen dapat dijelaskan sebagai berikut:

\section{Pengaruh Intellectual Capital (VAIC) terhadap Kinerja Perusahaan (ROE)}

Uji $t$ pengaruh modal intelektual (VAIC) terhadap kinerja perusahaan (ROE) menghasilkan t hitung sebesar 3,950 (arah positif) dengan p-value0,000 (sig. < 0,05) sehingga dapat disimpulkan bahwa modal intelektual berpengaruh positif dan signifikan terhadapkinerja perusahaan (hipotesis 1 diterima).

Modal intelektual mencerminkan intangible asset dimana knowledge dan skillmenjadi elemen yang penting dalam keberhasilan perusahaan. Riset ini membuktikan secara empiris bahwa pada 
bank - bank yang listed di IDX tahun 2017, modal intelektual akan mencerminkan kinerja perusahaan dalam menghasilkan laba (net incomedengan shareholders equity).Dalam riset -riset terkini dan juga dalam dunia bisnis, modal intelektual menjadi bagian yang sangat penting dalam menjalankan bisnis perusahaan dan akan membawa dampak yang baik bagi kinerja keuangan perusahaan (Belkaoui, 2008; Firer, 2003; Gan \& Saleh, 2008; Joshi et al., 2013).

\section{Pengaruh Budaya Perusahaan terhadap Kinerja Perusahaan $(R O E)$}

Uji t pengaruh budaya perusahaan collaboration-oriented culture (COL) terhadap kinerja keuangan menghasilkan t hitung sebesar 2,558 (arah positif) dengan p-value 0,016 (sig. < 0,05) sehingga dapat disimpulkan bahwacollaboration-oriented culture (COL)berpengaruh positif dan signifikan terhadap kinerja keuangan dan hipotesis 2 dalam penelitian ini diterima.

Collaboration-oriented cultureberorientasiteam workdan memiliki fokus pada pemberdayaan, partisipasi, komitmen dan loyalitas karyawan. Partisipasi yang tinggi dapat menciptakan rasa memiliki dan tanggung jawab terhadap organisasi (Kwarteng \& Aveh, 2018) dan mengakibatkan kinerja keuangan menjadi lebih baik. Hasil riset ini mendukung hasil - hasil sebelumnya bahwa budaya yang berorientasi tim terbukti berpengaruh positif dan signifikan terhadap kinerja keuangan. Semakin tinggi budaya kolaborasi akan meningkatkan kinerja keuangan perusahaan yang tercermin dengan ROE. Hasil ini mendukung penelitian yang dilakukan oleh Zhao et al. (2018)akan tetapi bertentangan dengan penelitian Gordon (1985), O'Reilly (1989).

Uji t pengaruh budaya perusahaan competition-oriented culture (COM) terhadap kinerja keuangan menghasilkan t hitung sebesar -3,262 (arah negatif) dengan p-value0,003 (sig. < 0,05) sehingga dapat disimpulkan bahwahipotesis 3 dalam penelitian ini diterima, competition-oriented culture (COM)berpengaruh negatif dan signifikan terhadap kinerja keuangan.

Hasil penelitian menunjukkan bahwa ketika budaya berorientas kompetisi ini meningkat, makan akan dapat menurunkan kinerja keuangan. Budaya ini memiliki orientasi pasar dan cenderung melakukan promosi besar - besaran dalam mendukung pemasaran produknya.Hal ini dinilai justru akan menjadi efek yang negatif bagi perusahana dikarenakan fokus konsumen tidak hanya pada promosi yang masif akan tetapi juga melihat kualitas dari produk/jasa yang dipasarkan.Biaya pemasaran sebagai akibat dari promosi justru dianggap dapat membebani perusahaan dan oleh karenanya menurunkan kinerja keuangan.

Uji t pengaruh budaya perusahaan control-oriented culture (CON) terhadap kinerja keuangan menghasilkan t hitung sebesar -0,926 (arah negatif) dengan p-value 0,362 (sig. >0,05) sehingga dapat disimpulkan bahwa control -oriented culture (CON)tidak berpengaruh terhadap kinerja keuangan.Hipotesis 4 dalam penelitian ini tidak diterima.

Control -oriented culturememfokuskan organisasi pada struktur organisasi/hirarki sehingga pengambilan keputusan dilakukan melalui tone from the top. Sistem budaya kontrol ini mengikuti tipe budaya tradisional/konvensional dimana sistem atasan - bawahan dilaksanakan melalui struktur organisasi yang ketat, pengelolaan melalui aturan dan job description yang jelas.Barney (1986)mengembangkan kerangka kerja untuk menilai apakah budaya berkontribusi dalam kinerja ekonomi.Budaya mampu meningkakan keunggulan kompetitif jika menambah nilai bagi perusahaan, langka, dan tidak bisa ditiru (imperfectly imitable).Lee \& Yu (2004) juga menyimpulkan dalam penelitiannya bahwa tidak semua budaya bisa mempengaruhi kinerja keuangan (tergantung jenis industrinya).Hasil penelitian ini menyimpulkan bahwa tidak ada hubungan antara budaya hirarki dengan kinerja keuangan, sejalan dengan penelitian Gordon (1985) dalam O'Reilly et al. (2014) bahwa tidak ada hubungan antara budaya perusahaan dengan profitabilitas atau pertumbuhan perusahaan.Control -oriented culturemerupakan budaya yang tradisional dan sudah diterapkan oleh perusahaan sejak dulu, bukan budaya yang langka dan imperfectly imitableoleh karenanya budaya ini tidak akan mempengaruhi kinerja perusahaan. 
Uji t pengaruh budaya perusahaan creation-oriented culture (CRE) terhadap kinerja keuangan menghasilkan t hitung sebesar 2,468 (arah positif) dengan p-value 0,020 (sig. < 0,05) sehingga dapat disimpulkan bahwa creation-oriented culture (CRE) berpengaruh positif dan signifikan terhadap kinerja keuangan.Hasil statistik mendukung hipotesis 5 dalam penelitian ini.Perusahaan dengan creation-oriented culturemengedepankan inovasi dan inisiatif yang dianggap akan membawa arah sumber daya baru, visi masa depan dan meningkatkan profitabilitas. Kemampuan adaptasi terhadap perubahan menjadi tolak ukur perusahaan yang memiliki tipe creation - oriented culture.Tiga aspek adaptasi menurut Fey \& Denison (2003), Nadler (1998) dalam Kwarteng \& Aveh (2018) adalah kapasitas untuk menciptakan perubahan, memahami keinginan konsumen dan berusaha untuk memenuhi kebutuhan konsumen tersebut, serta menjadi organisasi yang terus - menerus mengembangakn diri. Dengan ketiga aspek tersebut, akanberdampak pada keefektifan organisasi dan pada akhirnya akan meningkatkan kinerja keuangan. Oleh karenanya perusahaaan yang memiliki tingkat adaptasi tinggi terhadap perubahan dan selalu memunculkan inovasi (creation - oriented culture) akan memiliki kinerja keuangan yangbaik dibandingkan dengan yang tidak, sejalan dengan hasil penelitian ini.

\section{Kesimpulan}

Dari hasil uji statistik dapat disimpulkan bahwa modal intelektual, yang dihitung menggunakan VAIC, collaboration-oriented culture\&creation-oriented culture yang dihitung menggunakan aplikasi ATLAS.ti terbukti berpengaruh positif dan signifikan terhadap kinerja keuangan yang dihitung menggunakan ROE.Competition-oriented culture (COM) berpengaruh negatif dan signifikan terhadap kinerja keuangan sementaracontrol-oriented culture (CON) terbukti tidak berpengaruh terhadap kinerja keuangan.Modal intelektual akan menjadi bagian yang sangat penting dalam menjalankan bisnis perusahaan dan akan membawa dampak yang baik bagi kinerja keuangan perusahaan. Budaya collaboration - oriented culture (COL) berorientasi team work dan memiliki fokus pada pemberdayaan, partisipasi, komitmen dan loyalitas karyawan) dan memiliki dampak positif dalam meningkatkan kinerja keuangan.Budaya competition - oriented (COM) memiliki orientasi pasar dan memiliki biaya pemasaran yang tinggi, sehingga dianggap dapat membebani perusahaan dan oleh karenanya menurunkan kinerja keuangan.Control - oriented culture merupakan budaya yang tradisional dan sudah diterapkan oleh perusahaan sejak dulu, bukan budaya yang langka dan imperfectly imitable oleh karenanya budaya ini tidak akan mempengaruhi kinerja perusahaan. Perusahaaan yang memiliki tingkat adaptasi tinggi (creation - oriented / CRE), tanggap terhadap perubahan dan selalu memunculkan inovasi, dan oleh karenanya akan memiliki kinerja keuangan yang baik dibandingkan dengan yang tidak.

\section{Keterbatasan dan Saran}

Objek dari penelitian ini adalah bank - bank yang terdaftar di Bursa Efek Indonesia tahun 2017 dengan pertimbangan bahwa modal intelektual sangat dominan pada perusahaan yang bergerak pada jasa sektor keuangan. Model penghitungan modal intelektual menggunakan metode yang dikembangkan oleh Pulic (1998) yaitu menggunakan model VAIC. Masih banyak model - model lain yang bisa digunakan oleh peneliti selanjutnya. Ke depan, diharapkan objek penelitian lebih bervariasi dari beberapa sektor industri dengan periode penelitian yang lebih panjang atau bahkan bisa membandingkan beberapa sektor industri di beberapa negara. Model pengukuran corporate culture mengikuti dimensi budaya menurut Cameron (2006), banyak metode dimensi budaya yang dapat digunakan pada penelitian periode selanjutnya. 


\section{Daftar Pustaka}

Allen, M.R., and Wright, P.(2007).Strategic Management and HRM in the Oxford Handbook of Human Resource Management, Boxall, P., Purcell, J., and Wright, P. (eds.). Oxford University Press.

Ariningsih, Endah Pri. (2007). Pengaruh Budaya Organisasi pada Kinerja Perusahaan.Jurnal Segmen-Manajemen hlm.57-63.

Brahmasari, Ida Ayu. (2004). Pengaruh Variabel Budaya Perusahaan terhadap Komitmen Karyawan dan Kinerja Perusahaan Kelompok Penerbitan Pers Jawa Pos, Disertasi Universitas Airlangga, Surabaya.

Brennan, C. and Connell, B. (2000). Intellectual Capital: Current Issues and Policy Implications, Journal of Intellectual Capital Vol. 1.No.3, 206-240.

Cameron, K.S.; J. De Graff; R.E. Quinn; A. Thakor.(2006). Competing Values Leadership: Creating Value in Organisations. Edward Elgar, Cheltenham.

Cameron, Kim S dan Robert E Quinn.(2006). Diagnosing and Changing Oganizational Culture.A Wiley Imprint, San Fransisco.

Chen, M.C., Cheng, S.J., Hwang, Y. (2005). "An empirical investigation of the relationship between intellectual capital and firms' market value and financial performance”. Journal of Intellectual Capital.Vol. 6 N0. 2. pp. 159-176.

Ciptaningsih, Tri. (2013). Uji Pengaruh Modal Intelektual terhadap Kinerja Keuangan BUMN yang Go Public di Indonesia.Jurnal Manajemen Teknologi Volume 12 Number 3

Clarke, Martin, Dyna Seng, Rosalind H. Whiting. (2011). Intellectual capital and firm performance in Australia.Journal of Intellectual Capital Vol. 12 No. 4.Pp 505-530 (2011). Emerald Griup Publishing Limited.

Djuanda, Vincentius David., dan Tarigan, Josua. (2016). Pengaruh Budaya Organisasi terhadap Kinerja Keuangan melalui Perilaku Manajer atas Isu Manajemen Lingkungan sebagai Variabel Intervening.Bussines Accounting Review vol.4 No.1 hlm.61-72.

Edvinsson, L and Malone, M.S. (1997). Intellectual Capital: Realising Your Company's True value by Finding Its Hidden Brainpower, Harper Business, New York.

Edvinsson, L. and Malone, M. (1997).Intellectual Capital: Realizing Your Company's True Value by Finding Its Hidden Brainpower. HarperCollins, New York, NY.

Edward, Janice. Mastering Strategic Management 1St Canadian Edition. (2012). The B.C. Open Textbook Project.

Fiordelisi, Franco dan Ornella Ricci.(2014). Corporate Culture and CEO Turnover.Journal of Corporate Finance 28 (2014) 68-82.

Firer, S and Williams, M. (2003).Intellectual capital and traditional measures of corporate Performance.Journal of Intellectual Capital Vol.4, No.3, 348-60.

Freeman, R. Edward. (2010). Strategic Management: A Stakeholder Approach. Cambridge University Press.

Ghozali, Imam. (2018). Aplikasi Analisis Multivariate dengan Program IBM SPSS 25.Badan Penerbit Universitas Diponegoro.

Goh, P.C. (2005). Intellectual Capital performance of commercial banks in Malaysia, Journal of Intellectual Capital Vol.6, No. 3, 385-396.

Guthrie, J., Petty, R., Ferrier, F. and Well, R. (1999). "There is no accounting for intellectual capital in Australia: review of annual reporting practices and the internal measurement of intangibles within Australian organisations". Paper presented at the International Symposium Measuring and Reporting Intellectual Capital: Experiences, Issues and Prospects, OECD, Amsterdam, June. Available at: www.oecd.org. (accessed 02 Dec 2006). 
Hair Jr., Joseph F.; William C. Black; Barry J. Babin; Rolph E. Anderson.(2014). Multivariate Data Analysis 7th Edition.Pearson New International Edition.

Harrison, S., and Sullivan, P.H. (2000).Profitting form intellectual capital; Learning from leading companies. Journal of Intellectual Capital Vol. 1 No. 1. pp. 33-46.

Hermanto, Bambang., dan Rusdin. (2013). Budaya Organisasi, Penciptaan Nilai, dan Kinerja Organisasi. Bandung: Jurnal Administrasi Bisnis Vol.X, No.2, hlm.2982-2994 Universitas Padjajaran.

Hill, R., and Stewart, J. (2007). Management Development: Perspectives from Research and Practice, London: Routledge.

Huang, C.J., and Liu, C.J. (2005).Exploration for the relationship between innovation, IT and Performance, Journal of Intellectual Capital Vol.6, No.2, 237-252.

IASB (2004).Issues Standards on Business Combinations, Goodwill and Intangible Assets.International Accounting Standards Board.

International Federation of Accountants.(1998). The Measurement and Management of Intellectual Capital. available at: www.ifac.org. (Accessed January 2007).

Joshi, Mahesh; Daryll Cahill; Jasvinder Sidhu.(2013). Intellectual Capital and Financial Performance: an Evaluation of The Australian Financial Sector.Journal of Intellectual Capital Vol. 14 No. 2. Emerald Group Publishing Limited.

Kangarlouei, S. J., Motavassel, M., Azizi, A., \& Farahani, M. S. (2012). The investigation of the relationship between dividend policies, cash-flow uncertainty, contributed capital mix and investment opportunities: the case of emerging markets (Tehran Stock Exchange). International Journal of Business and Social Science, 3(2), 172-180.

Kwarteng, Amoako; Felix Aveh.(2018). Empirical examination of organizational culture on accounting information system and corporate performance, Evidence from a developing country perspective.2018. Meditari Accountancy Research Vol. 26 No. 4, 2018.Emerald Publishing Limited.

Lee, Siew Kim Jean; Kelvin Yu.(2004). Corporate culture and organizational performance.2004. Journal of Managerial Psychology Vol. 19 No. 4. Emerald Group Publishing Limited.

Lev, B. (2001). Intangibles: Management, and Reporting, Brookings Institution Press. Washington, $D C$.

Marchini, Pier Luigi; Carlotta D'Este.(2015). Comprehensive income and financial performance ratios: which potential effects on RoE and on firm's performance evaluation? Procedia Economics and Finance 32 (2015) 1724 - 1739. www.sciencedirect.com

Mondy, Wayne and Noe M. Robert.(1990). Human Resources Management.Fourth Edition.Allyn and Bacon. United States of America.

Naranjo-Valencia, Julia C.; Daniel Jimenez-Jimenez; Raquel Sanz-Valle.(2011). Innovation or imitation?The role of organizational culture.Management Decision Vol. 49 No. 1, 2011 pp. 55-72 q Emerald Group Publishing Limited.

Nurhayati, Enok; Lia Uzliawati. (2017). Intellectual Capital Disclosure Based Stakeholders Pada Perbankan Indonesia. Jurnal AkuntansiVolume XXI No. 03: September 2017: 484 496.

O'Reilly, Charles.(1989). Corporations, culture, and commitment: Motivation and social control in organizations. California Manage. Rev. 31, 9-25.

O'Reilly, Charles; David F. Caldwell, Jennifer A. Chatman; Bernadette Doerr.(2014). The Promise and Problems of Organizational Culture: CEO Personality, Culture, and Firm Performance.Group \& Organization Management 2014, Vol. 39 (6)

Petty, P. and Guthrie, J. (2000).Intellectual capital literature review: measurement, reporting and management. Journal of Intellectual Capital, Vol. 1 No. 2, pp. 155-75. 
Pulic, Ante. (2000). An accounting tool for IC management, Available online: http://www.measuring-ip.at/Papers/ham99txt.htm.

Pulic, Ante. (1998). Measuring the Performance of Intellectual Potential in Knowledge Economy. Presented in 1998 at the 2nd McMaster World Congress on Measuring and Managing Intellectual Capital by The Austrian Team for Intellectual Capital Potential.

Pulic, Ante. (2008). The Principles of Intellectual Capital Efficiency - A Brief Description. 2006. The Economist (2006), Economist Intelligence Unit, pp. 93.

Rakim, Aditya Achmad. (2014). Pengaruh Implementasi Budaya Perusahaan dan Value for Money terhadap Kinerja Perusahaan dengan Pendekatan Balanced Score Card: Corporate Governance sebagai Variabel Moderating. Serang: Skripsi Fakultas Ekonomi Jurusan Akuntansi Universitas Sultan Ageng Tirtayasa.

Rashid, Sambasivan; Murali Sambasivan; Juliana Johari.(2003). The influence of corporate culture and organizational commitment on performance. Journal of Management Development.Vol. 22, No. 8, pp. 708- 728.

Riahi-Belkaoui, A. (2003). Intellectual Capital and firm performance of US multinational firms: study of the resource-based and stakeholder views.Journal of Intellectual Capital Vol.4, No.2, 215-26.

Samiloglu, Famil;Ali Osman Oztop; Yunus Emre Kahraman. (2017). The Determinants of Firm Financial Performance: Evidence From Istanbul Stock Exchange (BIST). IOSR Journal of Economics and Finance (IOSR - JEF) Volume 8, Issue 6 Ver. I (Nov.- Dec .2017), PP 62-67 www.iosrjournals.org.

Schein, Edgar H. (2004). Organizational Culture and Leadership (Third Edition).A Wiley Imprint. San Fransisco, CA.

Shiu, H. (2006). The application of the Value Added Intellectual Coefficient to Measure Corporate Performance: Evidence from Technological Firms. International Journal of Management Vol.23, No.2, 356-365.

Siagian, Sondang P. (2002). "Fungsi Fungsi Manajerial." Jakarta: Bumi Aksara

Sørensen, J.B.(2002). The strength of corporate culture and the reliability of firm performance.Adm. Sci. Q. 47 (1), 70-91

Stewart, T.A. (1997). Intellectual Capital: The Wealth of New Organisations, Nicholas Brealey Publishing: London.

Sullivan Jr., P.H. and Sullivan Sr, P.H. (2000).Valuing intangible companies, an intellectual capital approach.Journal of Intellectual Capital Vol. 1 No. 4. pp. 328-340.

Sutanto, Natalia. I Gede Siswantaya.(2014). Pengaruh Modal Intelektual Terhadap Kinerja Perusahaan pada Perusahaan Perbankan yang Terdaftar di Bursa Efek Indonesia.MODUS Vol. $26(1): 1-17$

Sveiby, K.E. (1997). The New Organisational Wealth: Managing and Measuring Knowledge Based Assets. Berrett-Koehler. San Francisco, CA.

Ulum, Ihyaul MD. (2008). Intellectual Capital Performance Sektor Perbankan di Indonesia.Jurnal Akuntansi dan Keuangan, Vol. 10, No. 2, November 2008: 77-84.

Zhao, Hailin., Teng, Haimeng., Wu, Qiang.(2018). The effect of corporate culture on firm performance: Evidence from China. China Journal of Accounting Research 11 pp.1-19. 